Jnl of Ecclesiastical History, Vol. 72, No. 4, October 202 I. (C) The Author(s), 2021 . Published by Cambridge University Press. This is an Open Access article, distributed under the terms of the Creative Commons Attribution licence (http://creativecommons.org/licenses/by/4. $\mathrm{o} /$ ), which permits unrestricted re-use, distribution, and reproduction in any medium, provided the original work is properly cited. doi:10.1017/SoO22046921000026

\title{
Religion Subdued: The Political Figure of Christ in the Work of Giovanni Battista Comazzi (I654-I7II)
}

\author{
by MATTEO AL KALAK \\ University of Modena and Reggio Emilia \\ E-mail: matteo.alkalak@unimore.it
}

This article focuses on the work Politica e religione nella persona, parole ed azioni di Giesù Cristo (I7o6-7) by Giovanni Battista Comazzi, an emissary of the last duke of Mantua at the court of Vienna. Comazzi examined the actions and teachings of Christ described in the Gospel of John as a source for political guidance. The research reveals an attempt to establish an exegetical basis for challenging ecclesiastical interference, asserting the primacy of politics and advocating a poor and exemplary Church. Censored by the Holy Office, the work was ultimately framed within the clash between the papacy and the Empire.

7 he relationship between politics and religion, and the conflict between the spiritual and temporal realms, is one of the themes - that has always fascinated historians, not only in reference to the Christian West. The process of constructing what contemporary society refers to as secularism has been the subject of extensive research that has revealed the constant and unremitting friction between secular authorities and spiritual leaders. ${ }^{1}$ This state of tension has ancient origins and there

ACDF $=$ Archivio della Congregazione per la Dottrina della Fede: Archivum Sancti Offici Romani, Res doctrinales, Censurae, Vatican City; HHSA=Haus-, Hof- und Staatsarchiv, Wien; ÖNB = Österreichische Nationalbibliothek, Wien

1 This subject has an extensive bibliography, especially in relation to contemporary history and the case of France. The most prolific authors in this area include J. Casanova, Public religion in the modern world, Chicago 1994; R. Rémond, L'Invention de la lä̈cité française: de I789 à demain, Paris 2005; and J. Baubérot, Les Laïcités dans le monde, Paris 2007. 
have been a number of somewhat provocative suggestions that the formation of the first Christian community in fact marked the inception of secularism, in other words a distinction between the space of the $\dot{\varepsilon} \kappa \kappa \lambda \eta \sigma i \alpha$ (Church) and that of the State. ${ }^{2}$

The modern age, and in particular the turn of the eighteenth century, was a crucial period in this process which, through reformism, jurisdictionalism and later the Enlightenment, led to an irrevocable fracture, including in terms of the balance between religion and politics. ${ }^{3}$ This article aims to reflect on an episode that occurred during the historical moment that has been emotively referred to as the decline of Catholic Europe; 4 a period in which the role of the papacy in the continent's political order was harshly attacked by state jurisdictions seeking emancipation. The case in question is that of the diplomat Giovanni Battista Comazzi, the author of a commentary on the Gospel of John which identifies, based on the actions and words of Christ, teachings on the correct relationship between political and religious authorities. This study, which aims to draw attention to an author who is little known yet indicative of a crisis in relations between the Empire and the Holy See, is divided into three parts: firstly, it will retrace the key events in Comazzi's biography; next, it will examine his exegetical work; lastly, it will investigate the reactions of ecclesiastical censorship to the Italian diplomat's critical and at times irreverent pages. Finally, the conclusions will endeavour to place the work in a broader context to illustrate how it was part of an expanded strategy by means of which Habsburg politics sought to conquer and consolidate its hegemony over the Italian peninsula, clashing with the papacy and its fragile claims to power.

This analysis considers many factors, shedding light on the transformations that were underway. On the one hand, it reveals the growing politicisation of the figure of Christ and, more generally, of the biblical and evangelical message in the transition between the old regime and the Age of Enlightenment; on the other hand, there is an attempt to demolish, with the weapons of exegesis and religion, the claim of a potestas indirecta (indirect power) which, from Bellarmine onwards, was one of the arguments with which Rome justified its interference in sovereigns' decisions. 5

${ }^{2}$ This is the thesis of P. Prodi, Una storia della giustizia: dal pluralismo dei fori al moderno dualismo tra coscienza e diritto, Bologna 2000.

${ }^{3}$ For a brief overview of matters concerning the relationship between the political and religious spheres see D. Outram, The Enlightenment, 3rd edn, Cambridge 2013, $114^{-29}$.

4 This expression is from G. Signorotto, 'Il declino dell'Europa cattolica e il

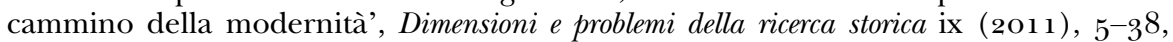
which has an exhaustive analysis of the historiography on the subject, among which see P. Hazard, La Crise de la conscience européenne (I 680-I 7 I 5), Paris 1934-5.

5 On the potestas indirecta and the debate on this subject see S. Tutino, Empire of souls: Robert Bellarmine and the Christian Commonwealth, New York 2010. 
On closer examination, other stories emerge: that of the links between Italian culture and the court of Vienna, where two women from the House of Gonzaga succeeded each other on the throne, bringing with them literary, artistic and musical figures $;^{6}$ and that of the Italian states, which were under increasing pressure from the European powers, as evidenced by the slow decline of the ancient and prestigious duchy of Mantua. The vicissitudes surrounding Comazzi's writings therefore offer an insight into the upheavals of an age of transition in which politics launched an attack on encroaching interference from Rome.

\section{The interests of an imperial historian}

Most of the scarce information that is available about the historian and diplomat Giovanni Battista Comazzi comes from biographical notes written in the late nineteenth century by the scholar Augusto Bazzoni. Bazzoni, who worked as an Italian consul in Austria from 1879, saw the documents containing Comazzi's written account of his life in the Court Archives in Vienna and obtained valuable information from them.7

Comazzi was born in Mantua in 1654 to a family originally from Monferrato. ${ }^{8}$ After training with the Jesuits, in 1682 he was appointed

6 Among the most recent publications on musical culture in the period considered here (and in relation to the Empress Eleonora II Gonzaga) see R. L. Kendrick, Fruits of the cross: Passiontide music theater in Habsburg Vienna, Oakland, $\mathrm{CA}_{2}$ 2019. On the court of Vienna and its transformations see J. Duindam, Vienna and Versailles: the courts of Europe's dynastic rivals, $1550-1780$, Cambridge 2003, and J. P. Spielman, The city and the crown: Vienna and the imperial court, I6oo-I74o, West Lafayette, IN 1993.

7 A. Bazzoni, 'Uno storiografo cesareo del secolo xvIII arrestato nei pressi di Vienna', Miscellanea di storia italiana 3 rd ser. i/2, (1895), 21-31. In Bazzoni's time, Comazzi's autobiographical notes were kept in the Court Archive in Vienna, under numbers 382 and 383 of the general catalogue, and consisted of two autographical files respectively containing 165 and around 300 papers. At present these documents are considered lost: more thorough research could make it possible to identify them within the thirty-three volumes of the Collectanea historica, nec non politica ac juridica (HHSA, Handschriftensammlung, ms W.706, formerly Ms 383) or in MS W.705 (formerly MS 382). Fieldwork remains to be done. On Bazzoni see G. Dissera Bragadin, Il console Augusto Bazzoni: scrittore veneto (I833-I894), Venice 1989.

8 The following information is taken, unless otherwise stated, from Bazzoni, 'Uno storiografo'; F. Vittori, 'Comazzi (Accomazzo), Giovanni Battista', in Dizionario biografico degli Italiani, Rome 1982, xxvii. 528-9; D. Pochi, 'Giovan Battista Comazzi, un pensatore politico tra Mantova e Vienna (1654-1711)', Annali di storia moderna e contemporanea iii (1997), 477-91; and, for the Viennese period, from the detailed reconstruction in S. Benz, Zwischen Tradition und Kritik: katholische Geschichtsschreibung im barocken Heiligen Römischen Reich, Husum 2003, particularly at pp. 364-7 (which also includes a complete bibliography). A testimony reported by F. Vecchiato indicates that Comazzi was born in Casale Monferrato (a claim also supported by Bazzoni): 'Tra 
resident minister in Vienna by Ferdinando Carlo Gonzaga-Nevers, the last duke of Mantua and Monferrato. He arrived at the court in February 1683. He immediately entered into the favour of Empress Eleonora Gonzaga, the widow of Ferdinand III of Habsburg, and in 1685 he was appointed court historian, succeeding Galeazzo Gualdo Priorato. Comazzi observed that the court was divided into two factions that respectively supported Eleonora and the reigning Emperor Leopold I, son of Ferdinand III and his first wife Maria Anna of Spain.

Comazzi's experience is connected to the alternating military and political events that characterised the Gonzaga's dominion in those years. Following the death of the last descendant of the Gonzagas, Vincenzo II, the European powers had mobilised to claim their rights in Mantuan territory. Specifically, Spain, the Empire and the duke of Savoy had opposed France, which supported Charles of Nevers, the father-in-law of Maria Gonzaga, the dynasty's last direct heir. In 1631 France emerged victorious and Mantua and Monferrato fell under the rule of the House of GonzagaNevers. ${ }^{9}$ Nevertheless, over the course of the following decades peace was not forthcoming in the small Po Valley state, which still found itself squeezed between France and the Empire at the end of the century. In this respect, the actions of Ferdinando Carlo, the last duke of Mantua, were disastrous. The duke not only sold the city of Casale to France in 1681, but was later declared a traitor and deposed by the Emperor Leopold I in 1701 . As a consequence of these events, Monferrato passed into the control of the duke of Savoy, while Mantua became part of the Empire.

The mistrust that surrounded Ferdinando Carlo, before his definitive fall into disgrace, involved Comazzi on several occasions, although the diplomat worked hard to maintain the duchy's political ties with the Empire. Shortly after his arrival in Vienna, news spread that Ferdinando Carlo had signed a treaty ceding Mantua to France: Comazzi returned to Italy to consult his employer, who reassured him that there was no such agreement. Not long afterwards, the incessant pursuit of money by the last of the Gonzagas led Mantua to once again yield to the Sun King's demands: Comazzi urged the court of Vienna to grant the duke a substantial pension as a way of dissuading him from his intentions. The situation was temporarily remedied but contact was subsequently resumed between the duke of Mantua and the French, leading to accusations of complicity being raised against Comazzi. An anonymous memorandum, dated 1684,

Asburgo e Borbone: la tragedia di Louis Canossa, ministro dell'ultimo duca di Mantova', Archivio veneto cxxviii, ser. v (1997), 67-130.

9 For a historical overview of the wars of Mantua and Monferrato see C. Mozzarelli, Mantova e $i$ Gonzaga dal ${ }_{3} 382$ al I707, Turin 1987, 110-22, and R. A. Strandling, 'Prelude to disaster: the precipitation of the War of the Mantuan Succession, 162729', HJxxxiii (1990), 769-85. 
advised the emperor to find an excuse to dismiss the diplomat, since 'essendo Monferino, [era] per conseguenza francese' ('being from Casale Monferrato, he was consequently French'). ${ }^{10}$ However, these voices were not heeded and Comazzi, on the contrary, demonstrated his dedication to the imperial cause. Indeed, his allegiance was proved by the attempt, ordered by Louis XIV, to poison him and his colleagues Luis of Canossa and Francesco Paleotti Lanzoni, proud opponents of any agreement between Mantua and France. ${ }^{11}$

In late 1707 , shortly before Ferdinando Carlo's deposition was formally decreed at the Diet of Regensburg (1708), there was yet another dramatic turn of events. On 13 November Comazzi was placed under house arrest in Nussdorf, a village then on the outskirts of Vienna. He was accused of having harboured an alleged French spy, the Franciscan Carlo of Guastalla, and above all of having offered the duke of Mantua the restitution of his estates in the name of the emperor.

Following an entreaty from Comazzi's daughter and pressure from various quarters, the emperor removed the guards outside the house of the defendant, who had to pledge that he would not flee. On 4 May 1708 he was finally released, but forbidden to go to court.

These events were probably a consequence of Comazzi's efforts to plead the duke of Mantua's cause to the very end. In 1707 he had addressed an oration to Joseph I in which he requested that the duchy of Mantua be restored to Ferdinando Carlo. In his petition, he presented Ferdinando Carlo as a weak prince, oppressed by the French and the great powers, who was now appealing to the emperor's clemency. The Mantuan envoys no longer attempted to counter the accusation of treachery, as they had done in previous years, but threw themselves on the mercy of Vienna, without invoking feudal law. ${ }^{12}$

In October 1707 Comazzi made a trip to Venice that aroused suspicions. Several of his detractors, perhaps envious of his position at court, spread the rumours of a secret mission: according to their account, Comazzi had offered Ferdinando Carlo the restitution of Mantua and Monferrato on behalf of the emperor, alarming Victor Amadeus II of Savoy.

Cleared of all these accusations, Comazzi's already difficult financial situation worsened: the entreaties of his wife Maria Helena Penz to the emperor reveal that the couple was burdened with debts and in this regard the expressions of esteem and acknowledgements that Comazzi

${ }^{10}$ The memorandum is kept in HHSA, Mantua, 6. This is reported in Vecchiato, 'Tra Asburgo e Borbone', 91.

${ }^{11}$ Vecchiato, 'Tra Asburgo e Borbone', 106-7 (who largely draws from Bazzoni).

${ }^{12}$ For an analysis of Comazzi's oration in Archivio di Stato, Mantua, Archivio Gonzaga, 6, fos 591r-6oov ('Fatto per quanto è stato detto dal d. conte Comazzi alla maestà dell'imperatore l'anno 1707 per il duca di Mantova') see D. Frigo, 'Impero, diritto feudale e "ragion di stato": la fine del ducato di Mantova (17011708)', Cheiron xxi (1994), 55-84. 
continued to receive until his death were of limited consequence. He died in Vienna on 27 March 1711.

Although his name is little known today, Comazzi's printed output carries a certain weight. ${ }^{13}$ He wrote many erudite works in which he used examples from antiquity to offer his readers norms of behaviour and virtue. This is the basis for La morale de' principi osservata nell'istoria di tutti gli imperatori [The morals of princes, or an abstract of the most remarkable passages contained in the history of all the emperors who reign'd in Rome] (Vienna: Sischowitz, 1689), a collection of teachings from the lives of the Roman emperors: the book was translated into English and French during the eighteenth century and was reprinted nine times. Antiquity was also the inspiration for Caracteres virorum ac foeminarum illustrium (Trento: Brunati, 1710), which catalogues the principal figures in Tacitus' works, as well as the Thesaurus expositus sive doctrina abscondita in C. Cornelii Taciti Annalibus (Vienna: Schönwetter, 1715), an analytical commentary on the first book of the Annals published by Comazzi's brother, Count Francesco Saverio, an official of the Hofkriegsrat, the Imperial War Council. ${ }^{14}$

Other works intertwine morality and politics, such as La mente del savio (Vienna: Sischowitz, 1684), which discusses the nature of wisdom and its religious implications, along with Politica e religione trovate insieme nella persona, parole ed azioni di Giesù Cristo ('Nicopoli: Folgori', 1706-7), which highlights the political content of the Gospel of John.

Two compendia range between theology and philosophy: La coscienza illuminata dalla teologia di san Tomaso d'Aquino (Cologne: Bauntir, $1710-$ 11), an epitome of Aquinas's teachings, and the Preliminari $\mathcal{E}^{2} c$. Politica cavata da otto libri del celebre maestro del Peripato Aristotile (Parma: Monti, 1740), published posthumously by Comazzi's nephew. ${ }^{15}$

Various works can also be attributed to his role as imperial historian. ${ }^{16} \mathrm{In}$ particular, Istoria di Leopoldo I (Vienna: eredi Viviani, 1686), Notitie historiche ... per

13 Unless otherwise stated, I have reworked the listing of Comazzi's works in Pochi, 'Giovan Battista Comazzi', 479-82. Information regarding first editions, titles and archival cataloguing of the manuscript texts has been checked and in several cases corrected.

${ }^{14}$ See Benz, Zwischen Tradition, 365-6.

${ }^{15}$ Pochi lists a 1710 Vienna edition of La coscienza illuminata of which I have not found any trace: 'Giovan Battista Comazzi', 480-1. With regard to the compendium on Aristotle's Politics, she could not identify any copies of the work. In the course of this research, copies of the text have been identified at the civic libraries of Biella and Fidenza, the Manfrediana Library of Faenza and the Oliveriana Library of Pesaro.

${ }^{16}$ On his production as a court historian see, as well as Benz, Zwischend Tradition, A. Strohmeyer, 'Nur Lorbeerkränze und Pietas? Herrschaft in der höfischen Geschichtsschreibung unter Leopold I', in M. Völkel and A. Strohmeyer (eds), Historiographie an europäischen Höfen (I 6.-I8. Jahrhundert), Berlin 2009, 61-95. 
la coronazione del re Giuseppe arciduca d'Austria (Venice: Albrizzi, 1688), ${ }^{17}$ Coronazione del re dell'Ungaria Giuseppe (Vienna: van Ghelen, 1688) and an unpublished Istoria della flotta cesarea sopra del Danubio, two copies of which remain in the Österreichische Nationalbibliothek in Vienna. ${ }^{18} \mathrm{~A}$ similar subject is covered in De rebus a Romano Imperatore Leopoldo gestis annis I 657, I658, I659, held at the Haus-, Hof- und Staatsarchiv, also in Vienna. ${ }^{19}$ Finally, Comazzi wrote a collection of sonnets entitled Filosofia et amore (Cologne: Bauntir, 1711), which has little literary merit and was inspired by the already dated Petrarchan model. Some of his writings are yet to be studied and would likely contribute relevant details to the Mantuan diplomat's biography. ${ }^{20}$

\section{Politics according to Jesus}

Comazzi was interested in many subjects, ranging from history to philosophy, politics and religion. Although his work is little known today, especially in comparison with the most influential thinkers who dominated the European stage in those years, his attempt to derive political teachings through a daring exegesis of the gospel text is none the less significant.

This, in short, is what the Mantuan diplomat attempted to accomplish with Politica e religione trovate insieme nella persona, parole ed azioni di Giesù Cristo. The text, divided into four volumes, appeared with false typographical information between 1706 and 1707 and in several subsequent reprints $(1708,1709,1710,1712$ and 1715$)$. The frontispiece indicates that the book was printed in Nicopoli by Evasio Folgori. However, the work was in fact published in Trento by Giovanni Antonio Brunati, whose printing house had also published other works by Comazzi. Brunati often altered typographical information, using, for example, the pseudonym Antonio Bauntir (an anagram of Brunati) and the false printing locations of Cologne and Vienna. In all likelihood he did so because he was aware of

\footnotetext{
${ }^{17}$ Pochi cites a 1687 Viennese edition that I was unable to locate: 'Giovan Battista Comazzi', $4^{81}$.

${ }_{18}$ Two copies exist: ÖNB, MSS 12461,8232 . According to Arno Strohmeyer, the text was also written in an attempt to gain political influence at court: 'Nur Lorbeerkränze', $69-70$.

${ }^{19}$ HHSA, Handschriftensammlung, ms W.5 8 . This was first reported in Pochi, 'Giovan Battista Comazzi', 482, which also refers (p. 482 n. 35 ) to other less significant unpublished works by Comazzi held at the Hofparteienprotokollen of the Obersthofmeisteramtes.

${ }^{20}$ I am referring in particular to Gli originali servigi all'augustissima Casa d'Austria del conte G.B. Comazzi and to the Giornale libro dell'arresto del conte G.B. Comazzi (HHSA, Handschriftensammlung, MS W.706/32, respectively fos 286-327 and 160-205), reported by Pochi, 'Giovan Battista Comazzi', 482.
} 
the 'dangerous' nature of some of the works he published and wanted to avoid, at least to some degree, the possible reprisals of censorship. ${ }^{21}$

Despite its unusual content, Comazzi's book does not appear to have received much attention in studies of political thought. Some brief references can be found in a monograph, dated 1914, by Arturo Carlo Jemolo, one of the most important scholars on the relations between the Church and State in Italy, who mentioned Comazzi's work in several footnotes without, however, dedicating particular attention to it. ${ }^{22}$ Another historian, Giorgio Spini, cited Comazzi at the conclusion of his study on libertines in seventeenth-century Italy. The political exegesis of the Gospel of John was given as an example of the anti-atheistic arguments that sought to oppose a now irreversible climate of cultural renewal: 'l'ottimo Comazzi' ('the excellent Comazzi'), wrote Spini, 'credeva in buona fede di rendere omaggio al Cristo ... ma si possono ben capire le ragioni per cui la Chiesa provvide tosto a condannare l'opera' ('believed in good faith that he was paying homage to Christ ... but one can easily understand why the Church was so quick to condemn his work'). ${ }^{23}$ It is important to stress that the Mantuan diplomat's work was presented as a response to the claims of seventeenth-century libertinism, contrary to what other historians have suggested. These include Fabio Martelli, who framed Comazzi's text as part of a project to oppose ecclesiastical interference, in close connection with the support for European libertinism advocated by General Raimondo Montecuccoli, who, Martelli alleges, commissioned the volume. ${ }^{24}$ Or Alessandro Catalano, who essentially identified theories not dissimilar to those of Machiavelli or indeed of Campanella and Tacitus. ${ }^{25}$

${ }^{21}$ For an identification of the printer and printing location see S. Groff, 'Contributo allo studio della tipografia trentina nel Settecento: ambito, strumenti e finalità di un censimento bibliografico', Studi trentini di scienze storiche lxxvii (1998), 265-334 at pp. $289-90$.

${ }^{22}$ A. C. Jemolo, Stato e Chiesa negli scrittori politici italiani del Seicento e del Settecento, Turin 1914 .

23 G. Spini, Ricerca dei libertini: la teoria dell'impostura delle religioni nel Seicento italiano, Florence 1983 (new revised and expanded edn of the original Rome $195^{\circ}$ edn), 386.

${ }^{24}$ F. Martelli, Le leggi, le armi e il principe: studi sul pensiero politico di Raimondo Montecuccoli, Bologna 1990, $465^{-7}$. Martelli does not specify the source of this information. Montecuccoli died in 1680 , when Comazzi had not yet reached the imperial court: it is therefore unclear in what context the idea of commissioning Comazzi to do the work arose. The only clue is in the dedicatory letter to the 1709 edition: in it the printer recalls that the first edition had 'nel suo primo nascimento la protezione d'un altissimo personaggio' ('the protection of a very high-ranking personage in its first conception').

${ }^{25}$ A. Catalano, 'Italská historiografie mezi machiavelismem a oslavou habsburské monarchie: politická ideologie a moralizující sebereflexe $\mathrm{v}$ dílech Raimonda Montecuccoliho, Galeazza Gualda Priorata a Giovanniho Battisty Comazziho', in V. 
The exegesis proposed by Comazzi has therefore been interpreted in various ways, revealing enigmatic traits and preserving ambiguous elements that have not been completely resolved. A brief analysis in a paper from 1981 also draws these conclusions. Exploring political readings of the figure of Christ, Daniele Menozzi, a scholar who has focused on the clash between Catholicism and political modernity, presents the Mantuan's work as a traditional text: he notes, however, the author's efforts to legitimise, through the Gospel, 'le astuzie e gli accorgimenti della politica' ('the tricks and ploys of politics'), ${ }^{26}$ using religion as a tool to confirm the prince's power.

These various judgements alone illustrate how hard it is to offer a clear vision of Comazzi's thought and work in which, in unsystematic and often inconsistent terms, Jesus' words and actions are examined. The structure and essential content of the text provide important clues about its aims and characteristics.

The four volumes map out a journey in one hundred chapters, preceded by a general introduction and completed by a last, unnumbered chapter that serves as a conclusion. Each chapter consists of a meditation on a verse from the Gospel of John, interpreted from a political standpoint. Examining the book on a superficial level, it is interesting to note how Comazzi concentrated on certain parts of the Fourth Gospel more than others and how references to chapters $\mathrm{xx}$ and $\mathrm{xxi}$, the passages that recount the stories of Jesus' resurrection, are completely absent.

Some important insights can be gained by examining how Comazzi's meditations are distributed over the various chapters of the Gospel (see Figure 1).

Observing the distribution, it is clear that Comazzi primarily focused on the section consisting of chapters vi-viii and, to a lesser extent, on chapters i-iii. Within this framework, the chapters that receive the most attention are, in order, numbers vi, viii and iii.

The sixth chapter opens with the feeding of the five thousand, which prompts the crowd to praise Jesus as king of Israel: the Messiah flees, rejecting the acclamation of the sated people and showing that he does not seek earthly recognition. It is a central point in John's narrative, which sheds light on the kingship of Christ and the interaction between religion and politics. ${ }^{27}$ The theme of the non-earthly nature of Christ's power

Bůžek and P. Král (eds), Společnost v zemich habsburské monarchie a jeji obraz v pramenech ( $1526-1740)$, České Budějovice 2006, $265^{-82 .}$

${ }_{26}$ D. Menozzi, 'Letture politiche della figura di Gesù nella cultura italiana del Settecento', in M. Rosa (ed.), Cattolicesimo e lumi nel Settecento italiano, Rome 1981, $127-76$ at p. 137 .

${ }^{27}$ For an overview of the concept of kingship in New Testament writings see B. Klappert, 'Kingdom', in The new international dictionary of New Testament theology, Grand Rapids, Mi $1975^{-8 .}$ 


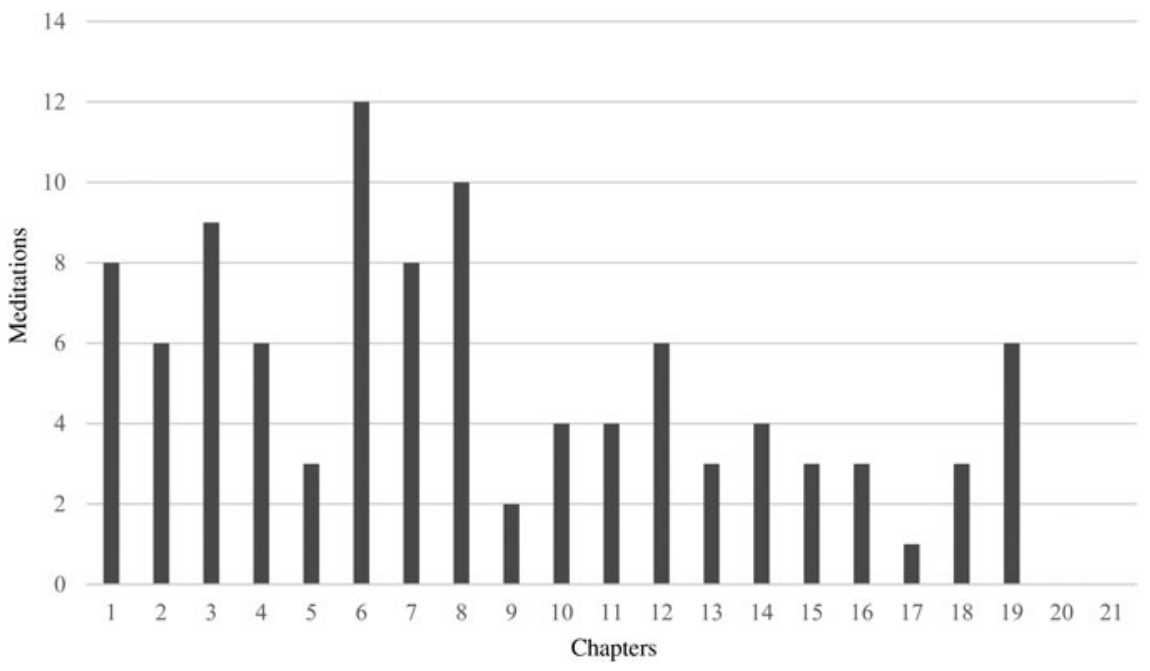

Figure 1. Meditations distributed by chapter in the Gospel of St John

periodically recurs in Comazzi's meditations and is a key to the interpretation of the whole work.

The eighth chapter in the Gospel of John - the second most discussed by Comazzi - is used to reflect on the difference between earthly justice and spiritual justice and on the diversity of the order in religion and government: Comazzi argues that men should be evaluated according to different criteria, depending on whether they are accountable to the prince or to the Church.

Finally, Comazzi discusses the third chapter, which contains the conversation between Jesus and Nicodemus, deducing various political teachings from Christ's pronouncements and presenting the relationship between God and the world, mediated through the sacrifice of the Son, as a reflection of the relationship between the prince and his subjects (in line with a more traditional and conventional model).

This analysis, based on quantitative evaluations, offers an initial key for deciphering the message that Comazzi intended to convey through his reflections on the Gospel. The next section will attempt to examine the implications of Comazzi's focus on these chapters-in particular the sixth - and what can be inferred from a more detailed reading of certain pages of the work.

\section{A kingdom beyond the world: Jesus' example}

Chapter vi of the Gospel of John is the one to which Comazzi paid particular attention, making it one of the cornerstones of his reflections. The 
commentary on verse $1_{5}$ ('Fugit iterum' ['He withdrew again']) provides valuable information on how the author addressed the theme of Christ's kingship, which dominates the Gospel passage. ${ }^{28}$ This reasoning was based on the need to distinguish political government from religion, preventing the latter from making claims to the power of princes. In several points, Comazzi insisted that religion is inadequate for political government, referring to the reversals that befell human societies when religion governed states and peoples. From the feeding of the five thousand, Comazzi, in scornful tones, deduces the following teaching: 'quella turba saziata dal miracolo di Giesù Cristo lo voleva avere per re, parendo a loro che non potrebbe desiderarsi meglior governo che dove il pane e le vivande moltiplicavano' ('that crowd sated by Jesus Christ's miracle wanted him as king, since they apparently could not wish for better government than one in which bread and food multiplied'). ${ }^{29}$ The people would have been more than happy to submit to a king who did not ask for tribute, but distributed food in abundance. However, he continued, this would not be the kingdom of religion, but the land of Cockaigne. Christ, in fact, had very different thoughts. Clear conclusions could be drawn from Jesus' behaviour and his flight: 'la religione che cerca principi non è religione, perché il principe della religione non può esser che Dio, né Dio ha bisogno che gli uomini lo eleggano re' ('religion that seeks princes is not religion, because the prince of religion can only be God, nor does God need men to elect him king'). $3^{\circ}$ Christ was king of the whole world and as a descendant of David he would have had the right to claim the sceptre of Israel: yet the wonders that he performed demonstrated that his kingship was different-it was not comparable to that of a sovereign and it was so powerful that it subverted the natural order. 'Il regno temporale del mondo non era il suo negozio' ('The temporal realm of the world was not his affair') ${ }^{31}$ and to show that political government did not interest him, Jesus had let Pilate's court judge him and had not resisted arrest. Comazzi therefore resolutely attacks the Church's claims to the temporal sphere: 'How much more glorious would our Church be if it had imitated the most holy and wise example of Jesus Christ when it was entreated by numerous earthly princes to be sovereign over their earthly conquests?' $3{ }^{2}$

The Church's attachment to power and the world, as well as its undue interference in political matters, are cited as the cause of all the schisms that plagued European Christianity. If the pope, Comazzi explains,

${ }^{28}$ G. B. Comazzi, Politica e religione trovate insieme nella persona, parole ed azioni di Giesù Cristo secondo l'Evangelio di san Gioanni, 'Nicopoli: Evasio Folgori', 1 7o6-7, ii, ch. xxxv.

${ }^{29}$ Ibid. $132 . \quad 3^{0}$ Ibid. 133 . ${ }^{31}$ Ibid. $13^{6 .}$

32 'Quanto più gloriosa sarebbe la nostra Chiesa se avesse imitato questo santissimo e sapientissimo esempio di Giesù Cristo, allora che fu ricercata da più principi terreni a costituirsi sovrana sopra delle loro terrene conquiste?': ibid. 139. 
drawing on a historical example, rather than handing Ferdinand the Catholic jurisdiction over the Indies discovered by Christopher Columbus, had instead refused Spain's request and sent missionaries to the new continent, adopting Jesus' words as his own ('Regnum meum non est de hoc mundo' ['My kingdom is not of this world']), Protestants would never have denied the vicarious position of the Roman pontiffs. 33 The Church should refrain from any interference in the earthly realm, imitating the model of Christ who had escaped from the crowd - that is, from kingship - without uttering a word: 'One must not only consider Christ's refusal to be king, but also observe the way he escaped without saying anything to them: when it comes to certain interests that concern the jealousy of the state and rulers, it is necessary not to enter into the matter, but rather to withdraw from it.' 34

Comazzi's vision could not have been clearer: a Church that adheres to the message of the Gospel must play a purely spiritual role. The church elite should not claim dominion over the world and influence over governments, nor seek to gain advantage in matters of state concern. The truth of this statement could also be deduced from accounts in the Old Testament. The experience of Moses - Jesus' precursor in Christian exegesis and, like him, the liberator of the chosen people - showed that religion was unsuitable, if not harmful, to man when applied to political government. In an ardent passage in the introduction, Comazzi recalls that in the time of Moses, when Israel was ruled by religion alone, the situation was deplorable. To govern a populace of 6oo,ooo men, plus women and children, 'sarebbe stata necessaria politica aver magistrati che lo regolassero, che lo provedessero, che lo frenassero' ('it would have been a politically prudent decision to appoint officials to regulate it, satisfy its needs and keep it in check').35 It required judges, engineers, government officials, army commanders etc. 'Si burlò Mosè di questa politica' ('Moses mocked this politics') and decided to proceed with miracles, which God granted him. These-Comazzi notes - should have been the happiest and best-governed people: yet 'non fu mai nazione nel mondo tanto difficile a maneggiare, tanto inquieta, tanto ingrata, tanto sacrilega; incontentabili, perfidi, ribelli; che più? idolatri in mezzo ai miracoli!' ('there was never a nation in the world so difficult to handle, so restless, so ungrateful, so sacrilegious; unappeasable, perfidious, rebellious; what more? Idolaters in the

33 Ibid. 140.

34 'Né basta considerare il rifiuto che fece Cristo d'esser re, ma deve inoltre osservarsi il modo che fu di fuggire senza dir loro alcuna sillaba: quando si tratta di certi interessi che toccano la gelosia di Stato ne' regnanti non bisogna né meno entrarne in discorso, ma bisogna affatto ritirarsene': ibid.

35 Ibid. i, introduction at pp. 18-22. The following quotations are also taken from here. 
midst of miracles!'). The ideal solution was not the one narrated by Scripture: instead it would have been preferable that 'mentre Moisè, ministro della religione parlava con Dio, altro ministro di politica avesse a certe ora distribuita la manna, ed a certe altre ore avesse fatta distribuere altra porzione di bastonate a coloro che mormorando nei conventicoli seminavan le turbolenze e sollevazioni del popolo' ('while Moses, a minister of religion, spoke with God, another minister of politics could have distributed manna at certain hours and at other hours he could have distributed another portion of beatings to those who murmured in secret meetings, sowing the seeds of turmoil and upheaval among the people'). Only the presence of two distinct areas and the correct division of duties would allow men to prosper on earth and reach eternal life. Although Comazzi's vision was not that of a prince without religion, but, on the contrary, that of a sovereign enlightened by faith - in a strictly confessional sense $3^{3}$ - it is none the less clear that, in his view, it was politics, rather than religious authority, that should manage worldly affairs. Moses and Jesus, from this perspective, were both unsuited to kingship: the former forced his people to undergo years of wandering that exposed them to all kinds of excesses, from idolatry to rebellion; the latter rejected the exercise of power by fleeing.

Christ's lack of earthly kingship could only produce a poor Church devoted to heavenly values. Comazzi's text thus became a fierce critique of the worldly excesses of pontiffs and prelates and a polemic against the religious orders to which families directed their children so that they would have some degree of financial security.

Shortly after the pages examined, in chapter xxxvii of Politica e religione Comazzi comments on John vi.26 ('Quaeritis me, quia manducastis' ['You are looking for me because you ate']), bitterly lashing out at those who used religion as a tool to obtain food and land. Innocent XI is referred to as an 'eroico esempio di religione dissenteressata' ('heroic example of disinterested religion') 37 because, after ascending to the Throne of St Peter, he did not draw on the riches of the Church for his own food, but

${ }^{36}$ In the thirty-third chapter, after railing against Jewish ministers and the custom of the courts of France and Austria to respectively admit Calvinists and Lutherans, Comazzi advocated that only officials of the same faith should be selected: 'Ha mostrata l'esperienza che non può essere unione di governo dove entrano a governare li ministri di religione diversa: ciascuno crede la propria religione migliore di quella degl'altri, e talora si crede obbligato di promoverla per ogni via, ancorché illegittima' ('Experience has shown that there can be no governmental union when ministers of different religions govern together: each believes his religion to be better than the others and at times they feel obliged to promote it by any means, however unlawful'): ibid. ii, ch. xxxiii, p. 113 . Shortly afterwards (pp. $115^{-16}$ ), he also observes that religious uniformity guarantees the prince greater obedience from his subjects.

37 Ibid. ii, ch. xxxvii, p. 163 . 
used his personal wealth, showing restraint and living a spartan life; by contrast, Comazzi pronounces very different judgements in regard to other religious figures. ${ }^{3}$ Many did not grasp the teaching of Jesus, who did not wish 'che la sua Chiesa debba risplendere per via di lusso e di fasto, ma per via di santi costumi ed eroiche virtù' ('that his Church should shine through luxury and splendour, but rather through holy customs and heroic virtues'): the Church's assets should not be used to display earthly power, but merely for sustenance. 39

These few examples effectively summarise the fundamental characteristics of Comazzi's thought: in various ways, he sought an evangelical foundation to counter the interference of ecclesiastical authorities. It is a theme that cyclically resurfaces in the course of the work, at times with more general statements and at others with concrete examples. In chapter lviii, reflecting on John xii.44 ('Jesus autem clamavit et dixit' ['Then Jesus cried out and said']), $4^{\circ}$ he severely criticises the use of spiritual weapons for political ends:

Religion requires that eternal life be preached to princes, since this is God's will: mandatum ejus vita aeterna est (His commandment is life everlasting), excommunication should not be inappropriately used as a threat; and politics requires that clergymen prevent overzealous preachers from instructing princes, as Jesus Christ did with the princes of Jerusalem: Jesus autem clamavit et dixit (Then Jesus cried out and said) $4^{1}$

The Church should keep within its boundaries, preach the kingdom of heaven and not issue excommunications for reasons unrelated to morality and doctrine. Clergymen are therefore obliged to treat princes with respect because they are entrusted by God to govern the world and are thus sacred. $4^{2}$ Jesus, caught in the act of fearlessly affirming his messianic identity against scribes and Pharisees, becomes a model for governments'

$3^{8}$ On the age of Innocent XI and the image of the pope saint see the overview in R. Bösel, A. Menniti Ippolito, A. Spiriti, C. Strinati and M. A. Visceglia (eds), Innocenzo XI Odescalchi: papa, politico, committente, Rome 2014.

39 Comazzi, Politica e religione ii, ch. xxxvii, p. 166.

$4^{\circ}$ Comazzi mistakenly designates the verse as John xi. $5^{\circ}$.

$4^{1}$ 'Vuol adunque la religione che si predichi ai principi la vita eterna, che questo è il comando di Dio: mandatum ejus vita aeterna est, e non si spaventino con minacciare scomuniche a sproposito; e la politica vorrebbe che gli ecclesiastici togliessero l'occasione a qualche zelante di alzar la voce all'istruzione de principi, come fece Giesù Cristo a principi di Gierusalemme: Jesus autem clamavit et dixit': Commazzi, Politica e religione iv, ch. lxxviii, p. 26.

$4^{2}$ 'Li principi sono anch'esse persone sacre non solamente per esser eletti o coronati nei sacri templi, con sacre funzioni ed onti con oglio sacro, ma per esser vicari di Dio, nell'amministrazione del governo del mondo' ('Princes are also sacred people not only because they are elected or crowned in sacred temples with sacred ceremonies in which they are anointed with sacred oil, but also because they are vicars of God in the administration of the world's government'): ibid. 
emancipation from the Church's desire to control them. Comazzi compares this to the actions of Sixtus $v$ who rejected the right of succession of Henry of Navarre (the future Henry iv), who was still a Huguenot, to the French crown. The latter, presenting himself before the then king of France Henry III, convinced the sovereign that the papal claims were unacceptable: 'Se si permetteva al papa di usurparsi autorità sopra le ragioni dei principi e distribuire i regni contro i dritti della natura, un'altra volta avrebbe pretese d'aver dominio sopra la sua stessa persona, fino a pretendere di poterlo deporre dal trono' ('If the pope was allowed to usurp authority over the rights of princes and distribute kingdoms against natural laws, in the future he would claim dominion over the king himself and even insist on his deposition from the throne'). 43 History, concluded Comazzi, demonstrated that this appeal was well-founded and that the Church, by pursuing the kingdoms of the earth, only risked destroying religion.

Comazzi's arguments reach their climax in the last chapters of the work, which examine the intense conversation between Christ and Pilate-the former the founder of a religion and the latter a representative of imperial power-and, in closing, the dramatic scene of the crucifixion. Commenting on John xviii.37 ('Rex sum ego' ['I am a king']), Comazzi summarises the basic principles that guide his exegesis of the Fourth Gospel. Jesus had clearly distinguished ecclesiastical and political government, and even in the Papal States, the two spheres - religious and temporal-were separate, proving that religion's role was to govern consciences. 44 Finally, considering the image of Jesus hanging on the cross, Comazzi argues that his nudity is a symbol of the spoliation required of the Church and its ministers.45 Evangelical poverty and detachment from earthly reality thus became an interpretative framework for reading the whole Gospel, from which a clear distinction between religion and politics emerges.

It is therefore evident that Comazzi chooses to dwell on the sixth chapter in particular because of the central importance of the topics that it covers, references to which can be found throughout the text.

\section{The Gospel in the Index}

Comazzi's work is multifaceted and cannot be exhaustively covered here. His meditations are not systematic and he repeatedly covers the same

43 Ibid. 47 .

44 Ibid. ch. xcv, pp. $263-4$. On the relationship between temporal administration and spiritual government in the late medieval and modern Papal States, an analysis that remains valid can be found in P. Prodi, The papal prince: one body and two souls: the papal monarchy in early Europe, Cambridge 1987.

45 See in particular Comazzi, Politica e religione, iv, ch. xcviii, pp. $295^{-9}$. 
ground. He blends erudition, examples from antiquity and exegetical interpretations that are not always relevant to the text and are at times fanciful. However, there is no doubt that the religious authorities were alarmed when he decided to tackle the Gospel of John. Comazzi's writings repeatedly drew the attention of the Catholic Church: many of his works were officially condemned and included in the Index..$^{6}$ As early as 1703 the congregation of the Holy Office took an interest in La mente del savio, which was the object of various censures by the Franciscan Serafino Gottarelli, a qualificator of the Holy Office, and from the Carmelites Liberio di Gesù and Mattia di Santa Maria.47 In this case, the congregation's suspicions were raised by topics touched on in the work, from the existence of God to the immortality of the soul and free will. The censors specified various corrections that needed to be made, but did not strongly condemn the work. Notably, one of the distortions that Liberio di Gesù singled out for correction was the inappropriate inclusion of the figure of Jesus among politicians ('Christum inter politicos videbitur adnumerare'), illustrating that the congregation and its officials were somewhat sensitive about this subject.

It was from 1711 onwards - the year of Comazzi's death - that the judges started to pay increasing attention to his works: this was the year in which $L a$ coscienza illuminata, which examined the theology of St Thomas (the decree of condemnation is dated 5 March 1711), and the commentary on the Gospel of John were added to the Index. Five years later, La morale dei principi (decree of 20 January 1 716 ) and the sonnets from the Filosofia et amore collection (decree of 27 April 1716) were banned.

With regard to Politica e religione, it is significant to note that the dangerous nature of the text was perceived both at a central and peripheral level. While the censors were at work on Comazzi's text in Rome, worried reports arrived from the local offices of the Inquisition. Among the papers of the Holy Office there is a letter in which Giuseppe Bauseri, the vicar of Finale (it is difficult to establish whether this was Finale in Emilia or the town of the same name in Liguria), denounced the circulation of Comazzi's text to the congregation. $4^{8}$ On 29 July 1711 Bauseri described

$4^{6}$ The following information, unless otherwise stated, is taken from J. M. de Bujanda (ed.), Index librorum prohibitorum, I6oo-1966, Montréal-Genève 2002, 234-5.

47 The following quotation is taken from ACDF, Censurae librorum, annorum 1704 et 1705 , file 7 . See also H. Wolf (ed.), Römische Inquisition und Indexkongregation: Grundlagenforschung, I7OI-I $I_{13}$, Paderborn-München-Wien-Zürich 2009-11, ii/1, 53-4. Some biographical notes on the three censors can be found respectively at iii/ 1, 627-9, 722-5; iii/2, 818-20.

$4^{8}$ ACDF, Tituli librorum, a mense novembris 1710 usque ad annum 1721 , file 11. The following information and quotation are taken from here. The edition denounced by Bauseri has the place and date of publication as Cologne 1709. The vicar suspected that the text had been published in Milan because of the printer's dedication to 
the work as a 'libro scandaloso contro la religione e che in alcuna parte spira empietà, non sente troppo bene de religiosi, dice male de prelati' ('a scandalous book against religion, which is at times impious and speaks unfavourably of priests and badly of prelates').

The letter confirmed the view of the Holy Office: the congregation had already discussed the case on 12 May 1711 , two months before Bauseri's denunciation, deciding that the book should be banned. It was the analysis conducted by Pier Francesco Zagnoni (Pier Francesco della Concezione), the former general of the Piarists, that convinced the judges. 49 The cleric's examination of the text left no room for doubt. Browsing through the pages of Comazzi's work - in the same Cologne 17 og edition that Bauseri had inspected-Zagnoni had identified the many dangerous errors that made it advisable to include the work in the Index. Three types of charges were levelled against Comazzi: method, moral order and dogmatic order. $5^{\circ}$ Firstly, emphasis was placed on the unacceptable nature of an exegesis that was not founded on the authority of the Scriptures, nor of the Doctors of the Church: the whole analysis was based on the mistaken deductions of Comazzi who, without following tradition, attributed dogmas and teachings to Christ that the Messiah had never expounded. $5^{1}$ This erroneous method led to conclusions that were audacious from a moral standpoint: commenting on Judas's betrayal, Comazzi stated, for example, that there should ideally be at least one wicked minister in every court, since his presence could help a prince to know where to find assassins, forgers and spies if it was necessary to carry out secret missions and to avenge serious crimes. $5^{2}$

Annibale Visconti, commander of the imperial army in Italy. However, the printer, who signed with the initials 'G.A.B.S.', can be identified as Giovanni Antonio Brunati, who was of Milanese origin, but active in Trento (see $\mathrm{n} .21$ above).

49 On Zagnoni (166o-1720), a qualificator of the Holy Office, advisor to the Congregation of the Index and exponent of the Accademia dell'Arcadia see G. M. Crescimbeni, Notizie istoriche degli arcadi morti, Rome: de Rossi, 1720-1, ii. 778o. For his work in the service of the Holy Office see Wolf, Römische Inquisition, iii/2, $1016-19$.

$5^{\circ}$ Zagnoni's censures, summarised and quoted below, are kept in: ACDF, Censurae librorum, ab anno 1711 ad annum 1714 , file 2. See Wolf, Römische Inquisition, ii/ 1, 115 .

$5^{1}$ 'Dum centena capita et ultra hic scriptor exarat, ad ea quae intendit probanda, mirum est quanta et qualia deducit, et sine sacrarum scripturarum auctoritate, sine sanctorum doctorum placito, plura coacervans, qualia Christo Domino tamquam ab ipso tradita quodammodo divinando imponat' ('While this writer offers hundreds of chapters to demonstrate what he aims to prove, the extent and nature of the things he deduces is astonishing, as is the manner in which - without the authority of sacred scripture and the consent of the Doctors of the Church - he musters these observations to make Christ the Lord say inconceivable things, presenting them as if they had been imparted by Christ'): ACDF, Censurae librorum, ab anno 1711 , file 2.

$5^{2}$ Zagnoni's reference is to G. B. Comazzi, Politica e religione trovate insieme nella persona, parole ed azioni di Giesù Cristo secondo l'Evangelo di san Giovanni, Cologne: 
However, Comazzi was viewed as a dangerous author above all because of the way in which he portrayed the relationship between politics and religion, with the latter subservient to the former ('hic auctor ... proponit ut politia [sic] non religioni inserviat, sed religio politiae ancilletur'). According to Comazzi the Church should have relinquished its earthly government and submitted to secular principles. Zagnoni railed against two passages in particular in which this content emerged unequivocally. In one section Comazzi called for a Church capable of imitating Christ without claiming to rule over the kingdoms of the earth.53 Another focused on Jesus' death sentence, from which Comazzi drew unacceptable conclusions:

Not only are clergymen in no way superior to temporal principles [Comazzi writes], but they are positively subject to them because Jesus Christ himself, as the formal head of our religion, wanted to be subject to temporal principles, by the authority of which he allowed himself to be imprisoned, judged and sentenced to death. 54

Zagnoni also recalled Comazzi's harsh attacks on theologians and religious orders. The former were accused of wanting to reconcile earthly philosophy, based on reason, with spiritual language at all costs. 55 Christ, in the Mantuan's opinion, had taught that religion should be based on Scripture and had never used any argument other than the sacred

Evasio Folgori, 1709 , iv, ch. lxxxi, p. 85: 'Per certe giustissime, ma pericolose o fiere spedizioni, da secretamente eseguirsi, si sa dove trovarne pronti gli esecutori: spie, imitatori dell'altrui scrittura, sicari, ed altri simili istromenti del regnare, che non saprebbonsi trovare da un ministro savio e santo, il ministro scellerato trova senza induggio e serve dove l'altro non può servire' ('For certain very just, but dangerous or daring expeditions, which must be carried out in secret, one knows where to find willing executors: spies, forgers of other people's writing, assassins and other similar tools of the realm, who cannot be found by a wise and saintly minister, yet a wicked minister does so without hesitation and serves where the other cannot serve').

53 In Comazzi, Politica e religione ( 1709 edn), the passage is at ii, ch. xxxv, p. 140.

54 'Non solamente non sono gli ecclesiastici in grado superiore a' principi temporali, ma gli sono positivamente sudditi perché Giesù Cristo stesso in questa formalità di nostro capo in religione volle constituirsi suddito de' principi temporali, dall'autorità de' quali si lasciò imprigionare, giudicare e condannare a morte': ibid. iv, ch. lxviii, p. 34 .

$55^{\prime}$ 'È cosa stranissima e degna di riso vedere nelle nostre università congregarsi tanti maestri della sacra teologia e schiarmazzare molte ore insieme come tanti pazzi furiosi, scatenati, e tutta la battaglia consiste perché vogliono spiegare il Testo divino con le sentenza di Aristotile, e chiudere in un medesimo portico l'Apocalissi e il Peripato, il linguaggio della filosofia terrena ed il linguaggio della religione celeste' ('It is very strange and laughable to see so many masters of sacred theology congregate in our universities and gabble away for hours together like unfettered lunatics, and the whole battle stems from their desire to explain the Divine Text with the judgements of Aristotle, and to enclose in the same portico the Apocalypse and the Peripatos, the language of earthly philosophy and the language of celestial religion'): ibid. i, ch. xviii, pp. $281-2$. 
text. $5^{6}$ This thesis, which Zagnoni described as being explicitly Lutheran, was accompanied by Comazzi's fierce and irreverent mockery of friars and monks:

Some [clergymen] let their beard grow down to their waist like savages, others square their beard in the shape of a broom, others shape it like a triangle on their lips and an oval on their chin; they cut their hair on their heads like a wig, a cap or a crown and some of them shave their heads like slaves ... They renounce everything they own, yet take their sustenance from the world that they claim to have renounced ... If the whole world were full of wise people, these inventions would pass for laughable comedies; but because ignorant common people make up most of the world, these rituals are therefore carefully invented.57

Comazzi's strident protest against the avarice and hypocrisy of the clergy ends by recalling how they subverted social hierarchies so that plebeians received greater honours than nobles and even became advisors and tutors to sovereigns. It is clear that the author opposed the interference of ecclesiastical authority in court life and, more generally, that the sentences singled out by the censor presented a picture in which the preeminence of politics undermined religion and its ministers.

It is therefore hardly surprising that Zagnoni's judgement was categorical. $5^{8}$ The book was scandalous: it would have disturbed the consciences of the faithful and it contained statements that were insulting to the

$5^{6}$ 'La religione scienza tutta si contiene nella sacra scrittura ... né Cristo stesso per confondere satanasso adoprò altri argomenti che un costante scriptum est, pieno di tanta forza, quanto era pieno di vanità quell' ipse dixit, ultima risposta dei scolari di Pittagora' ('The science of religion is all contained in the sacred scripture ... nor did Christ himself use other arguments to confound the Devil than a constant scriptum est, as full of strength as that ipse dixit, the last answer of the pupils of Pythagoras, was full of vanity'): ibid. $i$, introduction at p. 4 .

57 'Alcuni [religiosi] lascian crescere la barba sin alla cinta, come gente salvatica, altri la squadrano a forma di scope, altri l'impegolano a triangolo su le labbra ed ovale sul mento; li capelli su la testa li tagliano a perruchino, a berrettino, a corona, ed alcuni affatto rasi come tanti schiavi ... Rinonziano tutto il proprio e fanno venire le vettovaglie per la loro susistenza da quell'altro mondo a cui sono morti ... Se tutto il mondo fosse pieno di gente savia, queste invenzioni passerebbero per commedie da ridere; ma perché il volgo ignorante è la maggior parte del mondo, quindi sono questi riti prudentemente inventati': ibid. ii, ch. xxviii, pp. 39-40.

$5^{8}$ 'Coeterum cum in opere hoc, ut innuimus, ipsi Christo Iesu quodammodo multa imponantur, quasi capiendo eum in sermone, habeatque scriptor propositiones scandalosas, piarum aurium offensivas, temerarias, aliorum famae detrahentes, ecclesiasticam iurisdictionem laedentes, sacris personis iniuriosas ... opus ipsum ... prohibendo censeo' ('Moreover, since in this work, as previously stated, many things are attributed to Jesus Christ, as though taken directly from his preaching, and since this writer makes scandalous statements that offend the ears of the faithful, penning audacious words that slander the good name of others, undermine the power of the Church and insult the clergy ... I believe that this work ... should be forbidden'): ACDF, Censurae librorum, ab anno 1711 , file 2 . 
Church and its jurisdiction. The same conclusion was reached by the vicar of Finale, Bauseri, from the fringes of the network of officials and collaborators of the Holy Office, demonstrating that Comazzi's attack was dangerous to individuals of different backgrounds and cultural levels.

\section{A book and its framework: exegesis as politics}

This situation was probably not so different from that of other books which, for moral and doctrinal reasons, ended up in the Index and were censored by the religious authorities. The volume on the political reading of the Gospel of John, however, raises a number of questions which, although they have no easy answers, offer a glimpse into the complexity of the context in which Comazzi's work was situated. Beyond the differences between the various interpretations of the work, it certainly had a political purpose, closely reconnecting with the events of the first decade of the eighteenth century.

The War of the Spanish Succession, which began with the death of Charles II, who had no direct heirs, is a notable point of reference. The conflict, which pitted Philip v, grandson of the king of France, Louis XIV, and Charles of Habsburg (the future Emperor Charles vI) against each other, brought to light two very different political-cultural options: neoGhibellenism, embodied by the Empire, and a hispano-pontifical model which, especially in Italy, tried to ensure a stability. ${ }^{59}$ During this phase, the papacy sought to play an important role, especially in relation to the equilibrium of the Italian peninsula. Pope Clement XI, elected a few days after the death of Charles II, proved to be sympathetic to the French cause despite the declared neutrality of the Holy See. Support for Philip v was accompanied by the demands of the stricter wing of the Roman Curia (the so-called 'zelanti'), who defended the privileges of the Church, such as immunities and benefits, and the central political role of the papacy. ${ }^{60}$

The favour accorded to the French side was clearly perceived by its adversaries and the European powers. Austrian and papal interests had already

59 I have taken these two expressions and the following analysis from S. Tabacchi, 'L'impossibile neutralità: il papato, Roma e lo Stato della Chiesa durante la guerra di Successione spagnola', in A. Álvarez-Ossorio Álvariño (ed.), Famiglie nazioni e monarchia: il sistema europeo durante la Guerra di Successione spagnola, Cheiron xxxix-xl (2003), $223-43$.

60 On the election of Clement XI and the circumstances that led to it see S. Tabacchi, 'Cardinali zelanti e fazioni cardinalizie tra fine Seicento e inizio Settecento', in G. Signorotto and M. A. Visceglia (eds), La Corte di Roma tra Cinque e Seicento 'teatro' della politica europea, Rome 1998, 139-65. More generally see S. Andretta, 'Clemente XI', in Enciclopedia dei papi, Rome 2000, iii. 405-20 (with bibliography). 
begun to be in conflict in the late seventeenth century and, from 1704 , the military reinforcement of imperial troops in northern Italy severely escalated tensions. After the pope helped the French on the banks of the River Po, the Emperor Joseph I made a decision which symbolically demonstrated that the positions of the two sides were irreconcilable. On 15 July 1705 he ordered his ambassador in Rome to abandon the papal court and urged the apostolic nuncio in Vienna, Giovanni Antonio Davia, to leave the imperial residence. On the military front, in 1707 the Austrians defeated the French in the Po Valley and crossed the Papal States, indulging in acts of robbery and looting. Finally, in 1708 , after the imperial government had confiscated various ecclesiastical benefices in Milan and Naples and banned any transfer of money to Rome, the town of Comacchio, not far from Ferrara, was conquered (24 May 1708), triggering a major jurisdictional conflict that had repercussions at a European level. ${ }^{61}$

When placed in this context, Politica e religione acquires a very clear significance: the text revealed the tension between the Empire and the papacy, which surfaced on a number of occasions between the seventeenth and eighteenth centuries and was part of a wider strategy of challenging papal claims. The fact that the work was in Italian strengthened its message, explicitly addressing a geographical area over which Rome was striving to maintain its influence. While the first edition, which appeared between 1706 and 1707 , in the midst of the clash between Joseph I and Clement XI, maintained a guise of neutrality, the 1709 edition opened with a solemn dedication to Annibale Visconti, "presentemente comandante dell'armata in Italia per Sua Maestà Cesarea' ('presently commander of the army in Italy for His Majesty the Emperor'). ${ }^{62}$ At the height of the jurisdictional clash between the empire and the papacy, when the pontifical territory of Comacchio was occupied by Joseph I's troops and while the Spanish grip on Italy was weakening, starting in Milan, Comazzi's proposal for a poor Church, remote from worldly interests and political scheming, placed itself under the protection of a commander of the imperial army. The weapons of war and those of exegesis appear to have been engaged in the same battle against the Church's undue interference in international politics and state governance.

Interpreted from this perspective, Comazzi's work can thus be understood as part of a strategy to recover the prerogatives of politics, which was destined to bear fruit from the mid-eighteenth century onwards. The

${ }^{61}$ A reconstruction of the dispute over Comacchio can be found in S. Bertelli, Erudizione e storia in Ludovico Antonio Muratori, Naples 1960, 100-74.

62 'All'eccellenza illustrissima signor don Annibale marchese Visconti': Comazzi, Politica e religione (1709 edn). On Visconti see C. Donini, Il comandante supremo delle forze imperiali in Italia, Annibale Visconti da Brignano d'Adda, Treviglio $194^{2}$. 
Mantuan diplomat's erudition, his experience as an imperial historian and, last but not least, his philosophical and theological interests were opposed to ecclesiastical interference, resulting in an all-embracing clash that united the military and cultural spheres.

However, the political and, in many ways, propagandistic nature of Comazzi's exegesis fails to resolve one point: how much can the work be traced back to the libertine polemics of pre-Enlightenment Europe and how much to anti-atheism. Ultimately, religion does not appear to be challenged: the protest is aimed at the unduly excessive interference of the pope and the Roman Curia, as well as at the superstitious and hypocritical deviations of religious orders, yet the work views religion as an integral and defining element of the prince's power, the foundation of his sacred authority. Nevertheless, the fact that Comazzi's commentary excludes the chapters on the resurrection of Christ raises many questions. It is unlikely that this decision stemmed from a desire to deny, even in a veiled fashion, Jesus' divinity by emphasising his earthly nature: it is more probable that Comazzi omitted the chapters on the Messiah's glorious triumph in order to conclude his treatise with the scene that effectively sums up the work's core theme, namely Christ's voluntary and docile submission to the political authorities of his time. In this sense, the work can be included among a large series of pamphlets and essays that used the gospel teaching to challenge the Church's interference in the temporal sphere, with a compelling reference to the verse 'Regnum meum non est de hoc mundo' ('My kingdom is not of this world'), which had become 'an increasingly common refrain in anti-curialist attacks'. ${ }^{6} 3$ The triumph of earthly power over the Son of God was the culmination of Comazzi's argument, presenting a paradox which - without denying the divinity of Jesus - portrayed the radical otherness of the divine economy in comparison with the earthly order.

63 This expression is from S. J. Barnett, Idol temples and crafty priests: the origins of Enlightenment anticlericalism, Houndmills 1999, 69. 